\title{
Absence of p75 ${ }^{\mathrm{NTR}}$ Causes Increased Basal Forebrain Cholinergic Neuron Size, Choline Acetyltransferase Activity, and Target Innervation
}

\author{
Tracy T. Yeo, ${ }^{1}$ Jane Chua-Couzens, ${ }^{2}$ Larry L. Butcher, ${ }^{3}$ Dale E. Bredesen, ${ }^{4}$ Jonathan D. Cooper, ${ }^{2}$ \\ Janice S. Valletta, ${ }^{2}$ William C. Mobley, ${ }^{2}$ and Frank M. Longo ${ }^{1}$ \\ ${ }^{1}$ Department of Neurology, University of California at San Francisco/Veterans Affairs Medical Center, San Francisco, \\ California 94121, 2Departments of Neurology, Pediatrics, and the Neuroscience Program, University of California at San \\ Francisco, San Francisco, California 94143, ${ }^{3}$ Department of Psychology, University of California, Los Angeles, California \\ 90095, and 4 Program on Aging, The Burnham Institute, La Jolla, California 92037
}

\begin{abstract}
Emerging evidence suggests that the p75 neurotrophin receptor (p75 NTR) mediates cell death; however, it is not known whether $\mathrm{p} 75^{\mathrm{NTR}}$ negatively regulates other neuronal phenotypes. We found that mice null for $p 75^{N T R}$ displayed highly significant increases in the size of basal forebrain cholinergic neurons, including those that are TrkA-positive. Cholinergic hippocampal target innervation also was increased significantly. Activity of the cholinergic neurotransmitter synthetic enzyme choline acetyltransferase (ChAT) was increased in both the medial septum and hippocampus. Upregulation of these
\end{abstract}

cholinergic features was not associated with increased basal forebrain or hippocampal target NGF levels. In contrast, striatal cholinergic neurons, which do not express p75 NTR, showed no difference in neuronal number, size, or ChAT activity between wild-type and $p 75^{\mathrm{NTR}}$ null mutant mice. These findings indicate that $\mathrm{p} 75^{\mathrm{NTR}}$ negatively regulates cholinergic neuronal phenotype of the basal forebrain cholinergic neurons, including cell size, target innervation, and neurotransmitter synthesis.

Key words: $p 75^{\text {NTR; }}$ NGF; ChAT; TrkA; transgenic mice; basal forebrain; cholinergic neurons; hippocampus
Atrophy of basal forebrain cholinergic neurons and a marked decrease in cholinergic innervation of the hippocampus and cortex occur during aging and in neurodegenerative diseases (Tomlinson, 1992; Hendersen, 1996). Little is known of how these cholinergic neurotrophic features are regulated. Members of the neurotrophin family, in particular nerve growth factor (NGF), exert neurotrophic effects on basal forebrain cholinergic neurons. During development increasing levels of NGF coincide with increases in cholinergic neuronal size and target innervation (Korsching et al., 1985; Large et al., 1986; Auberger et al., 1987). Infusion of NGF causes profound increases in cholinergic neuronal size and choline acetyltransferase (ChAT) enzyme activity (Mobley et al., 1986; Higgins et al., 1989; Chen and Gage, 1995; Li et al., 1995), reverses cholinergic atrophy in aged animals (Fischer et al., 1987), and prevents neuronal atrophy and cell death after lesions of the septal-hippocampal pathway (Hefti et al., 1993; Koliatsos et al., 1994).

Several lines of indirect evidence suggest that $\mathrm{p} 75^{\mathrm{NTR}}$ plays an important role in regulating the trophic status of basal forebrain cholinergic neurons. In the basal forebrain $\mathrm{p} 75^{\mathrm{NTR}}$ expression is

\footnotetext{
Received March 20, 1997; revised July 24, 1997; accepted July 28, 1997.

This work was supported by National Institute of Aging Grant NIA-AG09873, Beeson Award from the American Federation for Aging Research, and Veterans Affairs Merit Review (to F.L.); French Foundation for Alzheimer's Research (to T.Y.); National Institutes of Health Grants NS24054 and AG10672, AG08938, and McGowan Charitable Trust (to W.C.M.); American Health Assistance Foundation (to D.B.); and Retirement Research Foundation of the University of California Los Angeles Center on Aging (to L.B.). We thank Dr. Julie Huber for providing mouse p $75^{\text {NTR }}$ exon 3 sequence for genotyping and Dr. Louis Reichardt for providing the RTA antibody.

Correspondence should be addressed to Dr. Frank M. Longo, Department of Neurology, V-127, University of California at San Francisco/Veterans Affairs Medical Center, 4150 Clement Street, San Francisco, CA 94121.

Copyright (C) 1997 Society for Neuroscience $0270-6474 / 97 / 177594-12 \$ 05.00 / 0$
}

colocalized exclusively with cholinergic neurons (Woolf et al., 1989a; Pioro and Cuello, 1990), and it is among the earliest cholinergic markers expressed during development (Yan and Johnson, 1988; Koh and Loy, 1989). Upregulation of p75 NTR expression correlates with developmental increases of NGF levels and cholinergic neuronal maturation (J. Springer, Y. Li, D. Holtzman, and W. Mobley, unpublished observation) and after exogenous NGF infusion (Higgins et al., 1989; Kojima et al., 1992). A role for $\mathrm{p} 75^{\mathrm{NTR}}$ in negatively mediating cholinergic neuronal survival is suggested by the observations that $\mathrm{p} 75^{\mathrm{NTR}}$ null mutant mice display an increase in cholinergic neuron number and a decrease in developmental cell death of basal forebrain neurons (Van der Zee et al., 1996). Expression of p $75^{\text {NTR }}$ also correlates with increased vulnerability of cholinergic neurons in Alzheimer's disease (Woolf et al., 1989b) and $\beta$-amyloid toxicity (Rabizadeh et al., 1994). The finding that the administration of $\mathrm{p} 75^{\text {NTR }}$ antibody significantly reduced cholinergic neuron sprouting suggests a role of $\mathrm{p} 75^{\mathrm{NTR}}$ in cholinergic neurite outgrowth (LucidiPhillipi et al., 1996).

To better define $\mathrm{p} 75^{\mathrm{NTR}}$ actions in the basal forebrain cholinergic system, we sought to examine its influences on neurotrophic features, including neuronal size, neurotransmitter synthesis, and target innervation. Two counterposed hypotheses can be formulated: under the first hypothesis $\mathrm{p} 75^{\mathrm{NTR}}$ acts to facilitate NGFinduced Trk-mediated function. This predicts that the absence of p $75^{\text {NTR }}$ would lead to a decrease in neuronal size, cholinergic enzyme activity, and/or target innervation. Under the second hypothesis $\mathrm{p} 75^{\mathrm{NTR}}$ has a negative neurotrophic effect. This predicts that the absence of $\mathrm{p} 75^{\text {NTR }}$ would lead to an increase in one or more of these parameters. These hypotheses were examined by assessing the medial septal-hippocampal cholinergic pathway 
(Butcher, 1995) in mice carrying a null mutation in one or both p75 ${ }^{\text {NTR }}$ alleles (Lee et al., 1992).

\section{MATERIALS AND METHODS}

Generation of $p 75^{N T R}$ knock-out mice colony and genotype identification. Original breeding pairs of mice homozygous for a null mutation in the p $75^{\text {NTR }}$ gene (p75 NTR $-/-$; Lee et al., 1992) were purchased from the Jackson Laboratory (Bar Harbor, ME). The strain background was a mixture of $\mathrm{C} 57 \mathrm{~B} 6 / \mathrm{BALB} / \mathrm{c} / 129$. Adult littermates (3-5 months old) consisting of wild-type controls $\left(\mathrm{p} 75^{\mathrm{NTR}}+/+\right)$ and mice heterozygous $\left(\mathrm{p} 75^{\mathrm{NTR}}+/-\right)$ or homozygous $\left(\mathrm{p} 75^{\mathrm{NTR}}-/-\right)$ for the $\mathrm{p} 75^{\mathrm{NTR}}$ mutation were used in the present study. They were generated as follows: $p 75^{\mathrm{NTR}}$ $-/-$ mice were backcrossed with wild-type mice from one of the parental strains $(\mathrm{BALB} / \mathrm{c})$ to generate heterozygous $\mathrm{F} 1$ progeny; these then were inbred via brother-sister mating to produce F2 progeny consisting of all three genotypes. Genotypes were determined by PCR of tail genomic DNA, as previously described (Yeo et al., 1997), using the following primers corresponding to sequences in exon 3 of the mouse p $75^{\text {NTR }}$ gene that is disrupted in the mutant allele and to sequences in the neomycin gene insert: $\mathrm{p} 75^{\mathrm{NTR}}$ sense/antisense, 5'-TGTTACGTTCTCTGACGTGGTGAG-3'/5'-TCAGCCCAGGGTGTGCA-CTC-3'; neomycin sense/ antisense, 5' -CATTCGACCACCAAGCGAAAC-3' $/ 5^{\prime}$-CAGCAATATCACGGGTAGCCAAC- $3^{\prime}$. A 345 bp product corresponding to the p $75^{\text {NTR }}$ gene was detected in $\mathrm{p} 75^{\mathrm{NTR}}+/+$, and a 294 bp product corresponding to the neomycin gene was detected in $\mathrm{p} 75^{\mathrm{NTR}}-/-$ mice; both products were detected in $\mathrm{p} 75^{\mathrm{NTR}}+/-$ mice.

Histological procedures. Histological procedures for ChAT immunoreactivity were performed according to previously described methods (Butcher, 1983; Gould et al., 1991; Yeo et al., 1997). Mice were perfused transcardially with cold $\left(4^{\circ} \mathrm{C}\right) \mathrm{PBS}$, followed by $4 \%$ paraformaldehyde containing $0.2 \%$ picric acid in $0.1 \mathrm{M}$ phosphate buffer. Brains were post-fixed in the same perfusion fixative and placed in $30 \%$ sucrose/PBS solution for at least $24 \mathrm{hr}$ for cryoprotection and cut into $30-\mu \mathrm{m}$-thick coronal sections with a vibratome. Two different antibodies, including a monoclonal ChAT antibody (Boehringer Mannheim, Indianapolis, IN) and a polyclonal AP144P antibody (Chemicon, Temecula, CA), initially were used for ChAT immunocytochemistry. These antibodies displayed similar qualitative and quantitative results for the staining of cholinergic cell bodies. However, because the AP144P antibody stained cholinergic fibers more intensely, only data obtained using this antibody were included. Sections were preincubated with $5 \%$ goat serum, followed by AP144P at 1:3000 dilution overnight at $4^{\circ} \mathrm{C}$, and then treated with biotinylated goat anti-rabbit $\operatorname{IgG}$ (1:250 dilution) and goat serum (1:80 dilution) in PBS. Staining was developed with avidin-biotin-peroxidase solution (ABC Elite kit, Vector Laboratories, Burlingame, CA) and intensified by diaminobenzidine (Sigma, St. Louis, MO) in 3.5\% nickel ammonium sulfate/PBS solution. A TrkA-specific polyclonal antibody RTA (generous gift of Dr. Louis Reichardt, UCSF; Clary et al., 1994), which recognizes TrkA but not TrkB or TrkC, was used for TrkA immunocytochemistry at the concentration of $1 \mu \mathrm{g} / \mathrm{ml}$ (affinity-purified $\mathrm{IgG})$, following a similar protocol.

Data analysis. Histological differences were evaluated by using unbiased stereology (optical disector) and a microcomputer imaging device (MCID) image analysis program (Image Research, Ontario, Canada) by at least two individual observers without the knowledge of the genotypes. The number and cross-sectional areas of ChAT-immunoreactive neurons in the medial septum, horizontal limb of the diagonal band, and striatum and of TrkA-immunoreactive neurons in the medial septum were analyzed. Serial sections of the entire medial septum (30- $\mu \mathrm{m}$-thick coronal sections) were collected on the basis of two anteroposterior anatomical landmarks: the meeting of the body of the corpus collosum at the midline marked the anterior boundary, and the midline crossing of the anterior commissure and the appearance of the fornix marked the posterior boundary. Every fourth section in this series was chosen, and a total of eight sections was used for data analysis. The reference space of the medial septum encompassed the triangular area that contains $95 \%$ or more of the basal forebrain cholinergic neurons dorsal to a line drawn across the tops of the anterior commissures. The same sections used for medial septum analysis were used for analysis of cholinergic neuron number and size in the striatum. For the horizontal limb of the diagonal band, only the medial part was analyzed, because the anterior portion of this nucleus merges with the vertical limb of the diagonal band and the posterior portion merges with the substantia innominata without clear boundaries that can be defined easily in an unbiased manner. Four sequential sections between the first appearance of fornix (anterior boundary) and the connection of lateral ventricles (posterior boundary) were assessed. Because each section contained a pair of diagonal bands, a total of eight diagonal band areas was analyzed from each animal.

The volume of each cholinergic nucleus was determined under a $4 \times$ objective by point counting after the superimposition of a $100 \mu \mathrm{m}^{2}$ grid. Cell number and cross-sectional areas were assessed under a $100 \times$ oil objective, and all cells with a clear nucleolus were measured. In some cases in which staining was too dark to reveal the nucleolus, only cells with clear neuronal morphology were measured. Because only every fourth section was analyzed (every $120 \mu \mathrm{m}$ ), it was unlikely that a neuron would be measured twice. The total number of neurons in each nucleus of each animal was estimated by the average number of neuronal profiles counted per optical disector volume multiplied by the volume of reference space of each nucleus. At least 80 disectors were used for estimating cell numbers in each nucleus, respectively, and a total of 100 neurons was assessed in each nucleus in each animal for measurement of crosssectional areas.

Cholinergic innervation of the hippocampal target was assessed visually by two individuals evaluating at least 10 sections per mouse. Then the number of cholinergic fibers in each hippocampal layer was measured by unbiased stereology and an MCID image analysis program. Slides were coded, and a total of five sections (every eighth section spanning the entire anterior hippocampus) was analyzed for each animal. A linear disector $(0.75 \mu \mathrm{m}$ wide and $330 \mu \mathrm{m}$ long $)$ was placed randomly on the screen, the density of ChAT immunoreactivity was scanned, and the number of ChAT-immunoreactive fibers in each layer was determined by counting the number of peaks crossing the disector.

ChAT enzyme assay. Animals were decapitated, and brains were removed and divided sagittally along the midline. The septum, hippocampus, and striatum were dissected on a chilled glass plate, as described previously (Johnston et al., 1987). Tissues were frozen immediately on dry ice and stored at $-70^{\circ} \mathrm{C}$. ChAT activity was determined by previously described procedures (Bull and Oderfeld-Nowak, 1971). Tissues were sonicated in $0.05 \mathrm{M}$ Tris-Triton buffer, $\mathrm{pH} 7.4$ (diluted 1:20, wet w/v), and centrifuged. The supernatant was transferred to another tube, and soluble protein levels were determined by bicinchoninic acid (BCA) assay (Pierce, Rockford, IL). Triplicate samples from each region of each animal were diluted 1:5 with Tris-phosphate buffer to a final volume of 50 $\mu$ l. Reaction cocktail ( $50 \mu \mathrm{l}$; containing $\mathrm{NaCl}$, eserine, choline chloride, albumin, and C14-labeled acetyl $\mathrm{CoA}$ in Na phosphate buffer) was added to the tissue sample, mixed, and incubated at $37^{\circ} \mathrm{C}$ for $30 \mathrm{~min}$. Background for each sample was determined by boiling tissue sample for 5 min before adding into the reaction cocktail. Reactions were stopped with $500 \mu \mathrm{l}$ of ice-cold $\mathrm{H}_{2} \mathrm{O}$ and loaded onto a column with 1 inch Dowex 1X-A beads (Bio-Rad, Hercules, CA). Columns were washed twice with

Table 1. Gross morphology of wild-type and $p 75^{\mathrm{NTR}}$ mutant mice

\begin{tabular}{lccc} 
Genotype & $\mathrm{p} 75^{\mathrm{NTR}}+/+$ & $\mathrm{p} 75^{\mathrm{NTR}}+/-$ & $\mathrm{p} 75^{\mathrm{NTR}}-/-$ \\
\hline Body weight $(\mathrm{gm})$ & $27.1 \pm 1.2(n=6)$ & $25.6 \pm 2.1(n=6)$ & $26.4 \pm 1.1(n=5)$ \\
Brain weight $(\mathrm{mg})$ & $458.3 \pm 4.3(n=6)$ & $461.5 \pm 6.9(n=6)$ & $448.0 \pm 1.6(n=5)$ \\
Number of sections with medial septum & $36.0 \pm 0.9(n=9)$ & $38.8 \pm 0.7(n=5)$ & $35.7 \pm 0.7(n=9)$ \\
Rostrocaudal length of MS $(\mu \mathrm{m})$ & $1080 \pm 28(n=9)$ & $1164 \pm 22(n=5)$ & $1070 \pm 22(n=9)$ \\
Volume of MS $\left(\mathrm{mm}^{3}\right)$ & $0.20 \pm 0.03(n=5)$ & $0.17 \pm 0.01(n=5)$ & $0.21 \pm 0.01(n=5)$
\end{tabular}

Mean \pm SEM. The rostrocaudal length of medial septum was calculated by multiplying the total number of consecutive sections $(30 \mu \mathrm{m}$ each) containing medial septum by $30 \mu \mathrm{m}$. The volume of medial septum was measured by unbiased stereology with optical disector; $n=$ number of animals. 

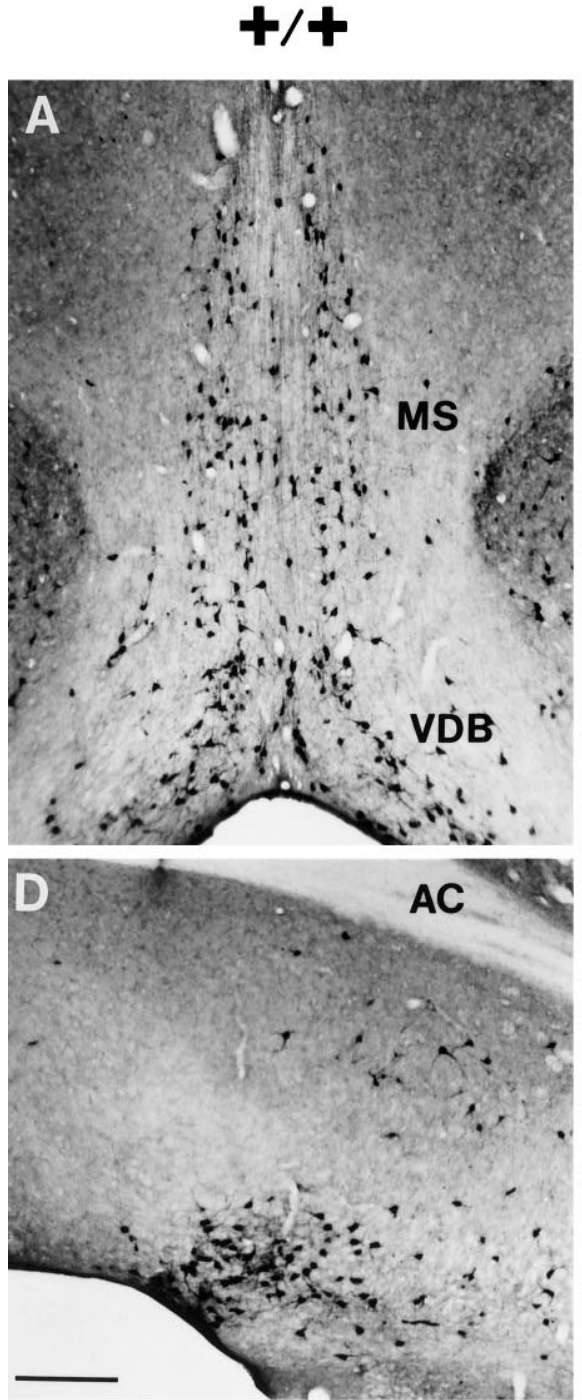

$+/-$
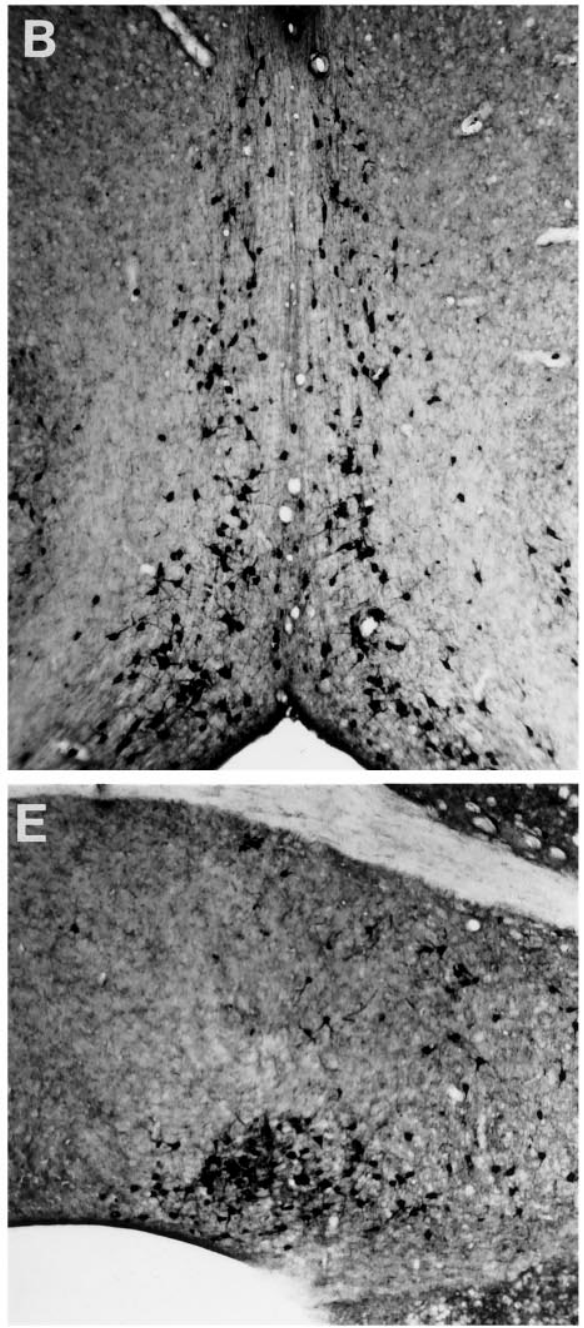

$-1-$
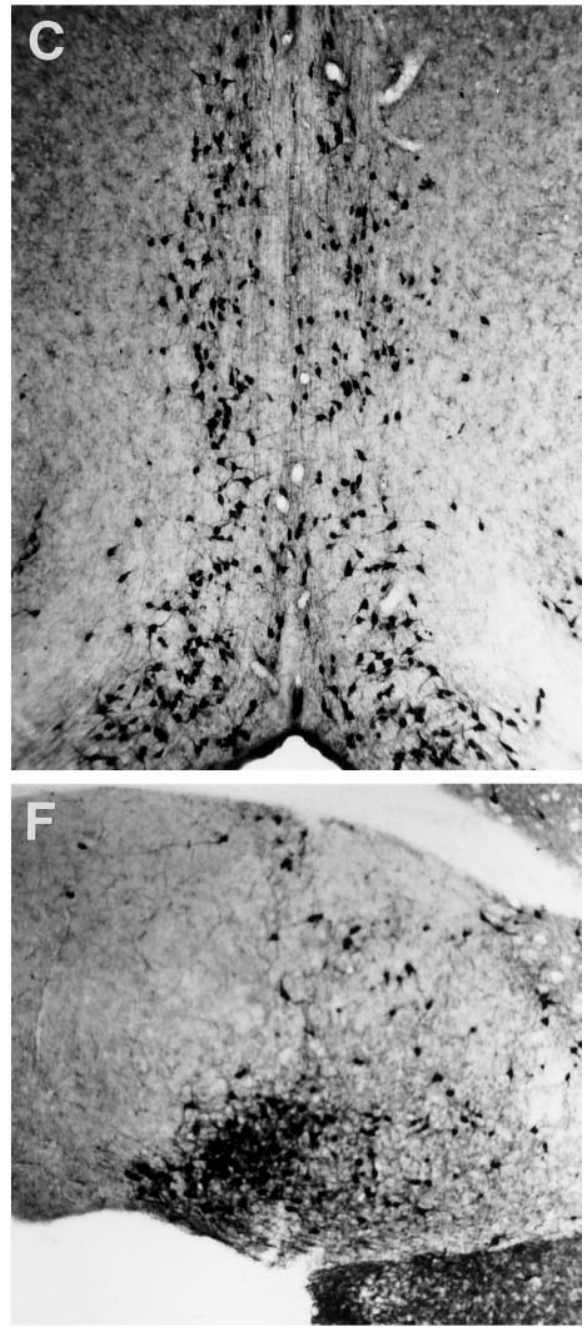

Figure 1. Basal forebrain cholinergic neurons in $\mathrm{p}^{\mathrm{NTR}}$-deficient mice. $A-C$, ChAT-immunoreactive neurons in the medial septum $(M S)$ and the vertical limb of the diagonal band $(V D B)$ in $75^{\mathrm{NTR}}+/+, \mathrm{p} 75^{\mathrm{NTR}}+/-$, and $75^{\mathrm{NTR}}-/-$ mice. $D-F$, ChAT-immunoreactive neurons in the horizontal limb of the diagonal band. The number of cholinergic neurons appeared greater in $\mathrm{p} 75^{\mathrm{NTR}}-/-$ mice. The size of cholinergic neurons appeared larger in both $\mathrm{p} 75^{\mathrm{NTR}}+/-$ and $\mathrm{p} 75^{\mathrm{NTR}}-/-$ mice. $A C$, Anterior commisure. Scale bar for coronal sections, $200 \mu \mathrm{m}$.

$600 \mu \mathrm{l}$ of $\mathrm{H}_{2} \mathrm{O}$, and all of the column effluents were collected and counted on the Beckman scintillation counter. The amount of acetylcholine synthesized was calculated and expressed as nanomoles per milligram of protein per hour.

NGF ELISA. Immunoassay for NGF levels was performed according to a previously published two-site NGF ELISA method (Mobley et al., 1989). Hippocampus, cingulate cortex, retrosplenial cortex, and the medial septal area, which contains both the medial septal nucleus and diagonal band (MS/DB), were dissected and immediately frozen on dry ice and stored at $-70^{\circ} \mathrm{C}$. Tissue extracts were prepared by $30 \mathrm{sec}$ of ultrasonication in $1: 9 \mathrm{w} / \mathrm{v}$ of cold sample buffer $(10 \mathrm{~mm}$ sodium phosphate buffer containing $400 \mathrm{~mm} \mathrm{NaCl}, 0.5 \%$ bovine serum albumin, and the proteinase inhibitors phenylmethylsulfonyl fluoride, benzethonium, and aprotinin). MS/DB were prepared in 1:4 w/v of cold sample buffer. In brief, 96-well plates (Nunc Maxisorp plates) were coated with goat anti-mouse NGF antiserum (GAM) or normal goat serum overnight, followed by the blocking of nonspecific binding for 2 hr. Supernatant of tissue extracts or individual NGF standards (ranging from 0 to $800 \mathrm{pg} / 100 \mu \mathrm{l})$ was added. NGF standards $(200 \mathrm{pg})$ were added to wild-type mouse cortex extracts to calculate total recovery. Plates were incubated overnight at $4^{\circ} \mathrm{C}$. Then monoclonal anti-mouse NGF antibody (1G3, Mobley et al., 1989) was added, followed by incubation with biotinylated goat anti-rat IgG. Immune sandwiches were detected by incubation with solutions containing $40 \mathrm{mg}$ of $O$ - phenylenediamine and $0.1 \% \mathrm{H}_{2} \mathrm{O}_{2}$ in $100 \mathrm{ml}$ of citrate phosphate buffer and stopped by the addition of $50 \mu \mathrm{l}$ of $2.5 \mathrm{M} \mathrm{H}_{2} \mathrm{SO}_{4}$. Optical density was measured at $492 \mathrm{~nm}$ and corrected for nonspecific binding by subtracting the reading of the samples added in wells coated with normal goat serum from the readings of the same samples added in wells coated with the goat anti-NGF antiserum. Absorbance for each sample was normalized to a standard curve and expressed as picograms of NGF per milligram of wet tissue weight.

\section{RESULTS}

The overall topography of the forebrain and its cholinergic neuronal perikarya is unchanged in p75 ${ }^{\text {NTR }}$-deficient mice

A previous report demonstrated that $\mathrm{p} 75^{\mathrm{NTR}}$ null mutant mice derived from a mixed strain background (C57B6/BALB/c/129, Jackson Laboratory) displayed an increased number of ChATimmunoreactive neurons in the medial septum as compared with each of three homogeneous strains (BALB/c, 129, and C57B6) of wild-type mice (Van der Zee et al., 1996). Given the possible effects of strain-specific factors and maternal abnormalities on offspring phenotype, we generated strain-matched 


\section{A.}
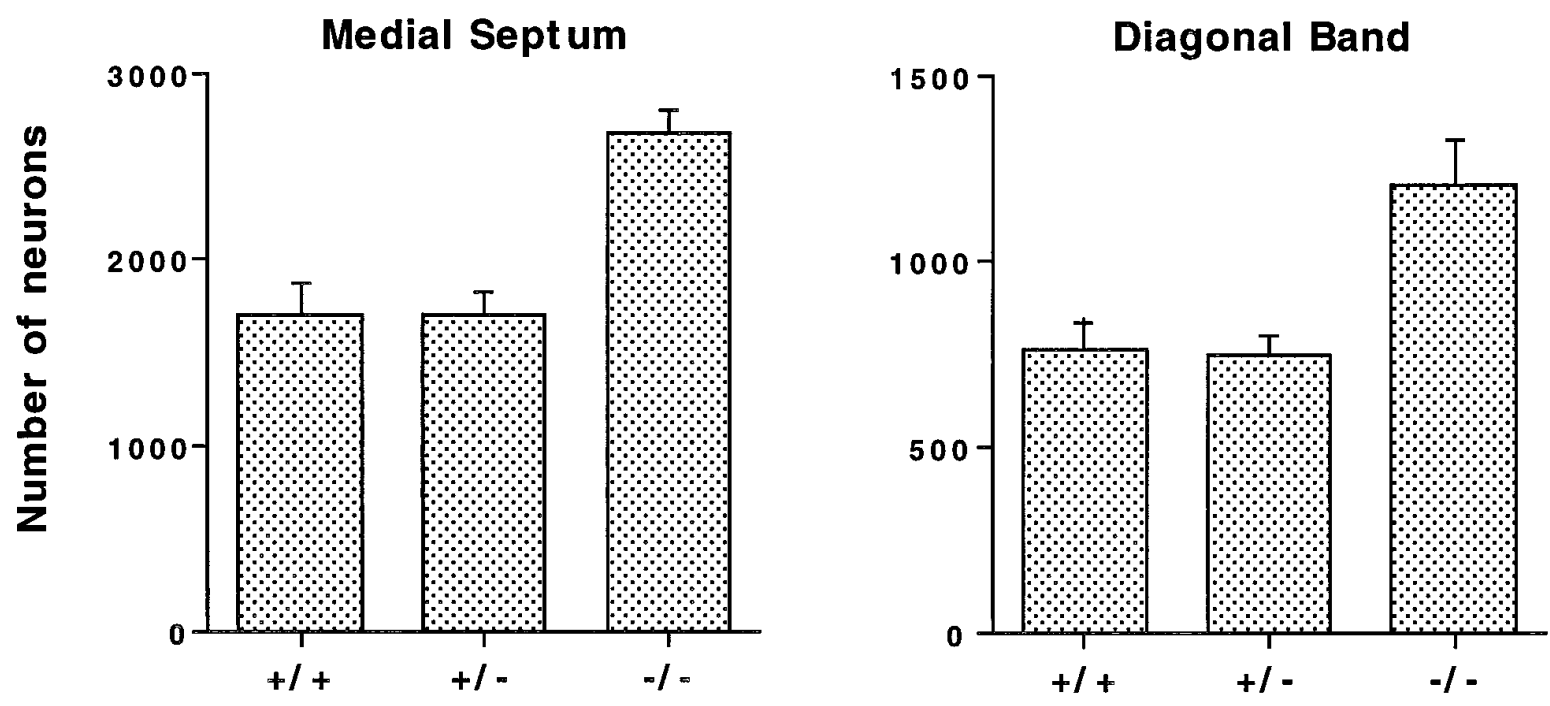

B.
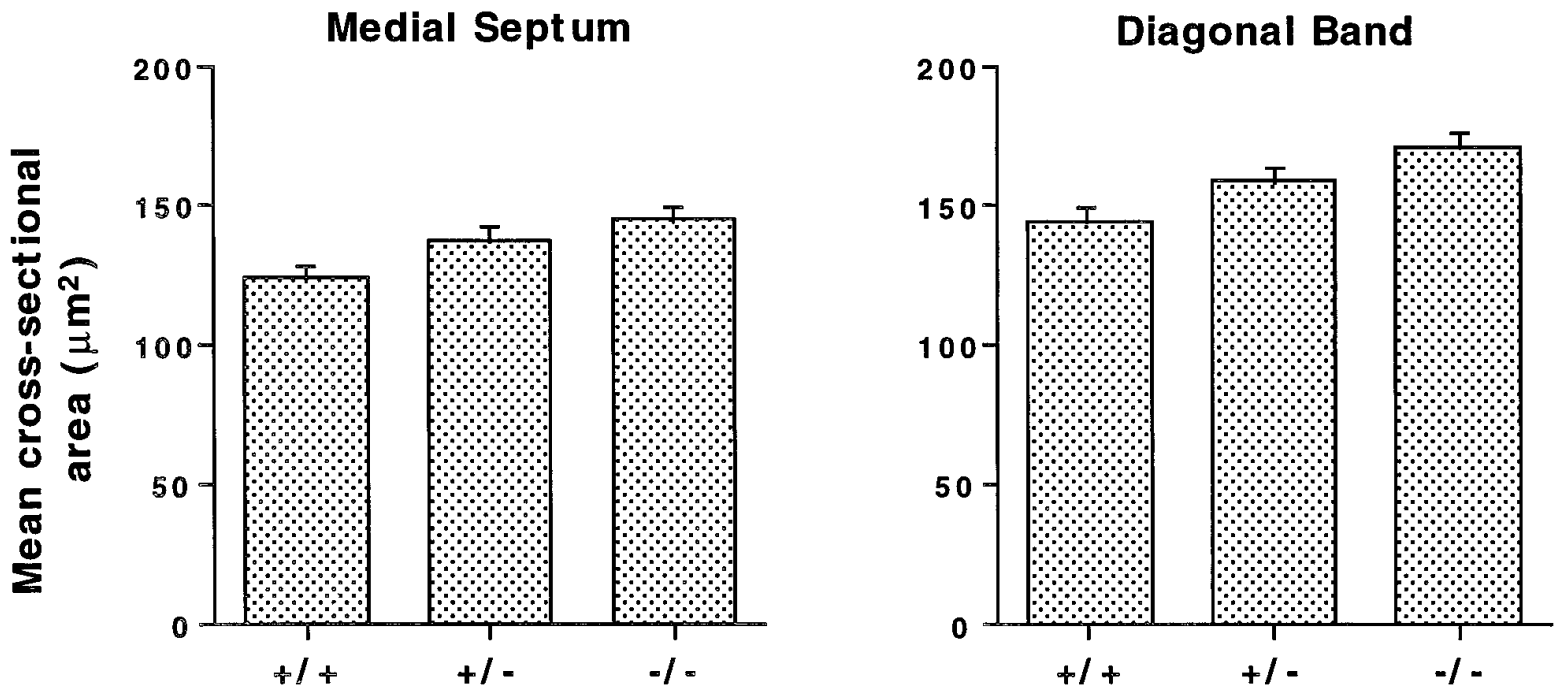

Figure 2. $\mathrm{p} 75^{\mathrm{NTR}}$ regulates the number and size of the basal forebrain cholinergic neurons. The number and cross-sectional areas of ChATimmunoreactive neurons were assessed, using unbiased stereology with optical disectors. $A$, The number of cholinergic neurons in the medial septum and horizontal limb of the diagonal band (Diagonal Band) was increased in both cholinergic nuclei in p $75^{\mathrm{NTR}}-/-$ mice, but not in p $75^{\mathrm{NTR}}+/-$ mice. For medial septum, $n=5$ mice for each genotype. The data are the number of ChAT-positive neurons per entire medial septum nucleus, presented as mean \pm SEM: $+/+=1708 \pm 206 ;+/-=1701 \pm 167 ;-/-=2677 \pm 165$. Student's $t$ test was used for statistical analysis: $+/+$ versus $+/-, p=0.978$; $+/+$ versus $-/-, p<0.01 ;+/-$ versus $-/-, p<0.005$. For diagonal band, $n=4$ mice for each genotype. The data are the number of ChAT-positive neurons per medial horizontal limb of the diagonal band nucleus, presented as mean \pm SEM: $+/+=764 \pm 101 ;+/-=748 \pm 73 ;-/-=1203 \pm 147$. Student's $t$ test was used for statistical analysis: $+/+$ versus $+/-, p=0.902 ;+/+$ versus $-/-, p<0.05 ;+/-$ versus $-/-, p<0.05$. $B$, Cross-sectional areas of cholinergic neurons in medial septum and diagonal band. For each of the two regions 100 neurons were measured per region per mouse, and four mice were analyzed per genotype. For medial septum, data are mean \pm SEM: $+/+=123.9 \mu \mathrm{m}^{2} \pm 1.8 ;+/-=136.9 \pm 1.9 ;-/-=144.5 \pm 2.4$. Student's $t$ test was used for statistical analysis, and $n=400$ neurons for each genotype: $+/+$ versus $+/-, p<0.0001 ;+/+$ versus $-/-, p<0.0001 ;+/-$ versus $-/-, p<0.05$. For diagonal band, data are mean \pm SEM: $+/+=143.7 \pm 2.4 ;+/-=158.8 \pm 2.7 ;-/-=170.9 \pm 2.87$. Student's $t$ test was used for statistical analysis, and $n=400$ neurons for each genotype: $+/+$ versus $+/-, p<0.0001 ;+/+$ versus $-/-, p<0.0001 ;+/-$ versus $-/-, p=0.005$.

littermate controls. Examination of adult (3-5 month old) $\mathrm{p} 75^{\mathrm{NTR}}+/+,+/-$, and $-/-$ littermates from five individual litters revealed no significant difference in body weight, brain weight (Table 1), or gross brain appearance. The number of 30 $\mu \mathrm{m}$ coronal sections encompassing the medial septum was unchanged across the three genotypes, indicating that the rostrocaudal dimension of the medial septum was not altered by the absence of the $\mathrm{p} 75^{\mathrm{NTR}}$ (Table 1 ). The volume of the medial septum, which was measured by unbiased stereology, also was unaffected by the p $75^{\mathrm{NTR}}$ genotypes (Table 1). The gross morphological appearance of basal forebrain cholinergic nuclei was assessed by ChAT immunocytochemistry. Exami- 


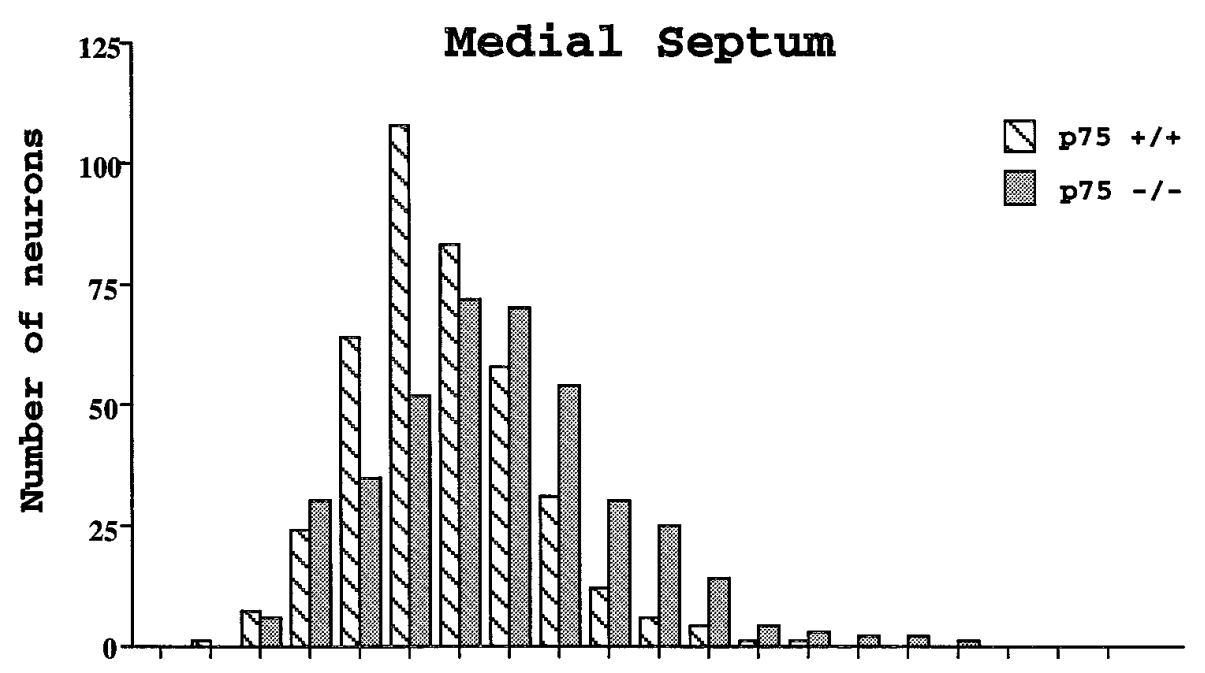

Figure 3. Size distribution of cholinergic neurons in medial septum and diagonal band. The distribution of the cross-sectional area of 400 ChAT-immunoreactive neurons was measured by unbiased stereology method for each basal forebrain cholinergic nucleus in the medial septum (top panel) and diagonal band (bottom panel) for each genotype (p75 ${ }^{\mathrm{NTR}}+/+$, striped bar; $75^{\mathrm{NTR}}-1-$, shaded bar). One hundred neurons were measured in each nucleus in each animal. A total of four animals was analyzed for each genotype. The number of neurons counted in each of the $20 \mu \mathrm{m}^{2}$ intervals is shown. In each case the shift in size distribution was mainly unimodal.

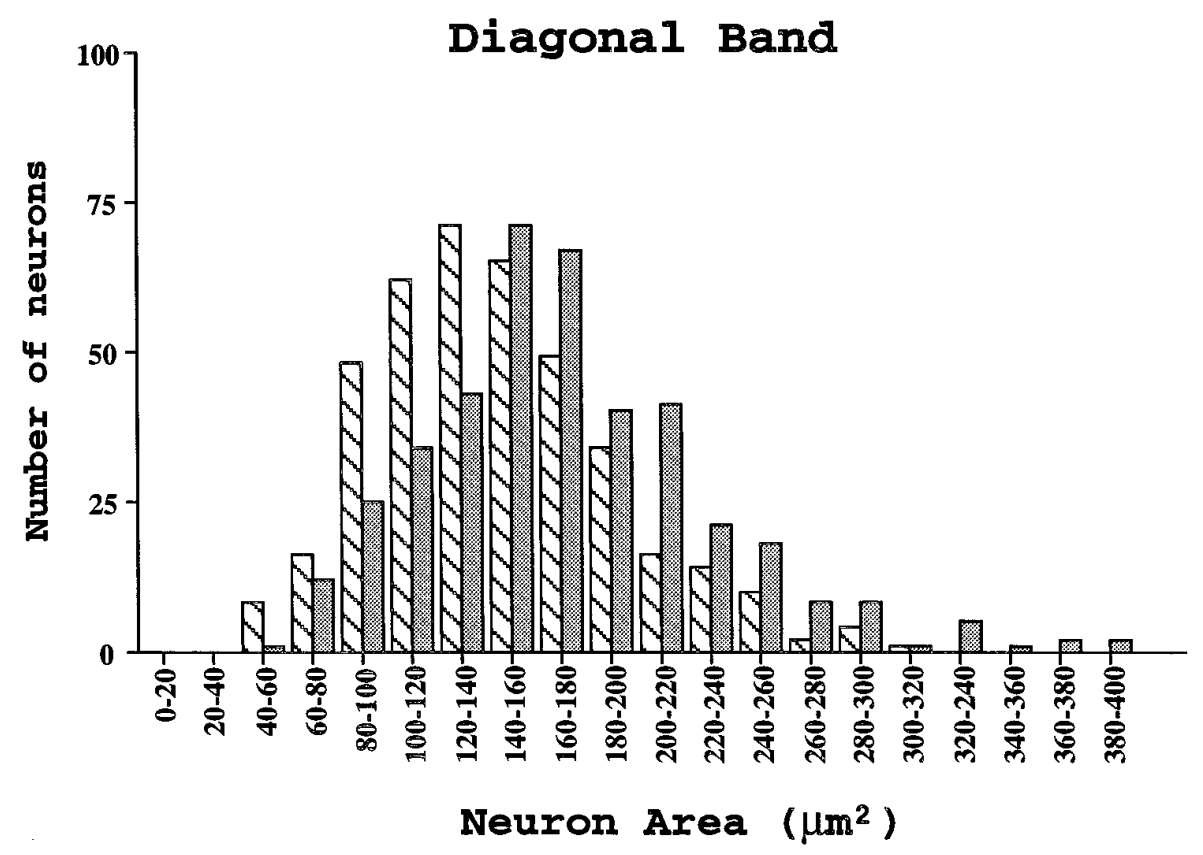

nation of all three genotypes detected ChAT-immunoreactive neurons in appropriate basal forebrain locations in the medial septum, vertical and horizontal limbs of the diagonal band (Fig. 1), magnocellular preoptic area, nucleus basalis of Meyert, and substantia innominata (data not shown). In all three genotypes, cholinergic innervation, as revealed by two well characterized cholinergic markers, ChAT immunoreactivity and acetylcholinesterase (AChE) staining, were present in the expected cortical and hippocampal target areas. These observations demonstrate that the lack of $\mathrm{p} 75^{\mathrm{NTR}}$ does not preclude neurogenesis or migration of basal forebrain cholinergic neurons or have obvious effects on these parameters for other neurons.

The number of ChAT-immunoreactive neurons in the basal forebrain was increased in p75 ${ }^{\mathrm{NTR}}-/-$ mice, but

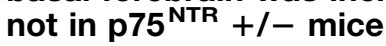

As shown in Figure 1, there was an apparent increase in the number of ChAT-immunoreactive neurons in the medial sep- tum in mice null for $\mathrm{p} 75^{\mathrm{NTR}}\left(\mathrm{p} 75^{\mathrm{NTR}}-/-\right)$, but not in heterozygous mice $\left(\mathrm{p} 75^{\mathrm{NTR}}+/-\right)$. A similar increase in the number of ChAT-immunoreactive neurons also was found in the vertical and horizontal limbs of the diagonal band (Fig. 1), indicating that the effect of $\mathrm{p} 75^{\mathrm{NTR}}$ on neuronal number was not confined to the medial septum. Quantitative analysis that used unbiased stereological methods to analyze the entire nucleus revealed a significant increase of $\sim 50 \%$ in the number of ChAT-immunoreactive neurons in both the medial septum and the diagonal band in $\mathrm{p} 75^{\mathrm{NTR}}-/-$ mice (Fig. $2 A$ ). Because there was no significant difference in the rostrocaudal dimensions of medial septum or the volume of medial septum among the three genotypes (Table 1), the increase in cells counted in p $75^{\text {NTR }}-/-$ mice reflected an absolute increase in total ChAT-immunoreactive neuronal number and not an increase in cell density. There was no significant difference in the number of ChAT-immunoreactive neurons between p $75^{\text {NTR }}$ $+/+$ and $\mathrm{p} 75^{\mathrm{NTR}}+/-$ mice, indicating that disruption of 

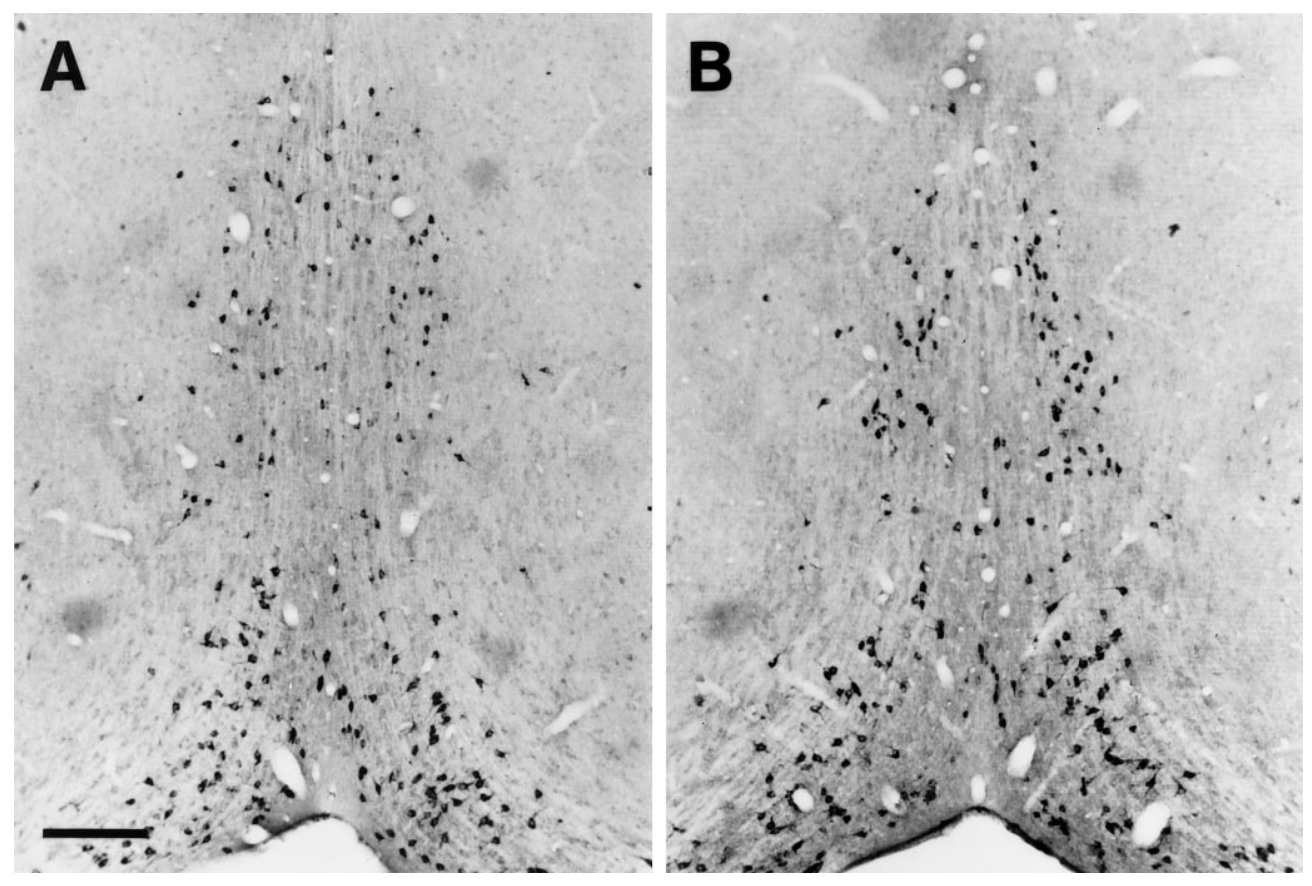

Figure 4. TrkA-immunoreactive neurons in $\mathrm{p} 75^{\mathrm{NTR}}$ null mutant mice. Shown is TrkA immunostaining of the media septum in $\mathrm{p}^{75^{\mathrm{NTR}}}+/+(A)$ and p $75^{\text {NTR }}-/-(B)$ mice. The size of TrkA-immunoreactive neurons appeared larger in $\mathrm{p} 75^{\mathrm{NTR}}-/-$ mice. Coronal sections, scale bar, $200 \mu \mathrm{m}$. both alleles was required to cause an increase in neuronal number.

\section{p75 ${ }^{\text {NTR }}$-deficient mice display gene dosage-dependent hypertrophy of cholinergic neurons}

In contrast to neuron number, measurement of neuron size demonstrated a clear gene dosage effect of $\mathrm{p} 75^{\mathrm{NTR}}$ in the phenotype of the basal forebrain cholinergic neurons (Fig. 2B). The mean cross-sectional area of cholinergic neurons in medial septum was $10 \%$ larger in $\mathrm{p} 75^{\mathrm{NTR}}+/-$ and $17 \%$ larger in $\mathrm{p} 75^{\mathrm{NTR}}-/-$ mice, as compared with $\mathrm{p} 75^{\mathrm{NTR}}+1+$ mice. ANOVA across the three genotypes demonstrated a highly significant $(p<0.0001)$ gene dosage effect on neuronal size (nonparametric Kruskal-Wallis ANOVA test, $n=400$ neurons for each genotype). A gene dosage effect on neuronal size also was found in the diagonal band. The mean cross-sectional area of cholinergic neurons was $11 \%$ larger in $\mathrm{p} 75^{\mathrm{NTR}}+/-$ and $19 \%$ larger in $\mathrm{p} 75^{\mathrm{NTR}}-/-$ mice, as compared with $\mathrm{p} 75^{\mathrm{NTR}}+/+$ mice. ANOVA across the three genotypes demonstrated a highly significant $(p<0.0001)$ gene dosage effect on neuronal size (nonparametric Kruskal-Wallis ANOVA test, $n=400$ neurons for each genotype). Comparison of the cholinergic neuron size distribution between $\mathrm{p} 75^{\mathrm{NTR}}+/+$ and p $75^{\text {NTR }}-1-$ mice (Fig. 3) revealed that there was an increase in size among all ChAT-immunoreactive neurons in both the medial septum and diagonal band. The distribution appeared unimodal in both p $75^{\mathrm{NTR}}+/+$ and p $75^{\mathrm{NTR}}-/-$ mice.

\section{Absence of $\mathrm{p} 75^{\mathrm{NTR}}$ causes hypertrophy of TrkA-immunoreactive neurons}

In the previous study demonstrating an increased number of cholinergic neurons in p $75^{\text {NTR }}$ null mutant mice (Van der Zee et al., 1996), no increase in the number of TrkA-immunoreactive neurons was observed. In contrast to the lack of effect on TrkAimmunoreactive cell number, the present study demonstrated a clear increase in the cross-sectional area of TrkA-immunoreactive neurons in p75 NTR $-/-$ mice (Fig. 4). Quantitative analysis by unbiased stereology revealed a significant $16 \%$ increase $(p<$ 0.01 ; Mann-Whitney test, $n=5$ mice for each genotype; 100 neurons measured for each mouse) in the cross-sectional area of TrkA-immunoreactive neurons in $\mathrm{p} 75-/-$ mice $\left(\mathrm{p} 75^{\mathrm{NTR}}+/+\right.$, $87.8 \pm 1.7 \mathrm{vs} \mathrm{p} 75^{\mathrm{NTR}}-/-, 102.0 \pm 2.0 \mu \mathrm{m}^{2}$ ). The increase in size of the TrkA-immunoreactive neuronal population was similar to that observed in the overall population of ChAT-immunoreactive neurons.

\section{Absence of $\mathrm{p} 75^{\mathrm{NTR}}$ causes increased cholinergic innervation of the hippocampus}

Cholinergic neurons in the medial septum, as well as certain of those in the diagonal band, project primarily to the hippocampus, where they terminate in layers adjacent to the pyramidal and granular cell layers (Butcher, 1995). The laminar patterns of hippocampal p75 NTR innervation parallel those of ChAT (Pioro and Cuello, 1990). Cholinergic innervation of the hippocampus was visualized by ChAT immunostaining (Fig. 5). In p75 NTR $+/+$ mice, ChAT-immunoreactive fibers were especially prominent in the suprapyramidal layer, and moderate ChAT immunostaining was also present in the oriens layer and stratum radiatum (Fig. 5A). In the dentate gyrus moderate ChAT immunostaining also was observed in the hilus and supragranular and molecular layers (Fig. 5C). Nissl staining detected no difference in hippocampal laminar structure between $\mathrm{p} 75^{\mathrm{NTR}}+/+$ and $-/-$ mice (data not shown). In $\mathrm{p} 75^{\mathrm{NTR}}+/-$ mice no qualitative changes in hippocampal innervation were noted. In $\mathrm{p} 75^{\mathrm{NTR}}-/-$ mice there was an overall increase in the number of ChAT-immunoreactive fibers in the hippocampus, although the increase did not occur in all layers. In the CA region the density of ChAT immunostaining was increased markedly in the oriens layer and stratum radiatum (Fig. 5B). In contrast, in the suprapyramidal layer, which is heavily innervated in $\mathrm{p} 75^{\mathrm{NTR}}+/+$ mice, a profound decrease in ChAT staining was observed in p $75^{\mathrm{NTR}}-/-$ mice. In the dentate gyrus a dramatic increase in ChAT immunostaining was observed in the supragranular layer, especially along the boundary between the granular cell and supragranular layers and along the boundary between the supragranular and molecular layers (Fig. 5D). A modest increase in ChAT staining also was observed in the 


\section{$+1+$}
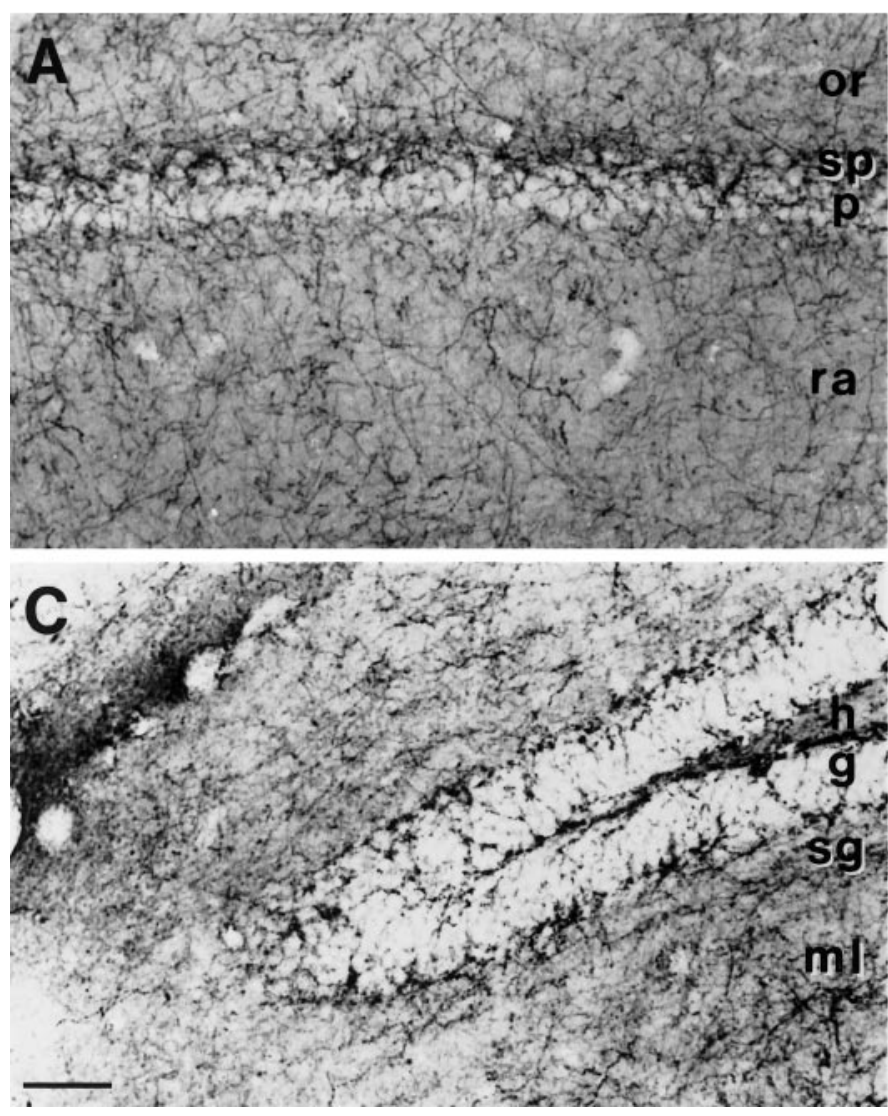

$-1-$
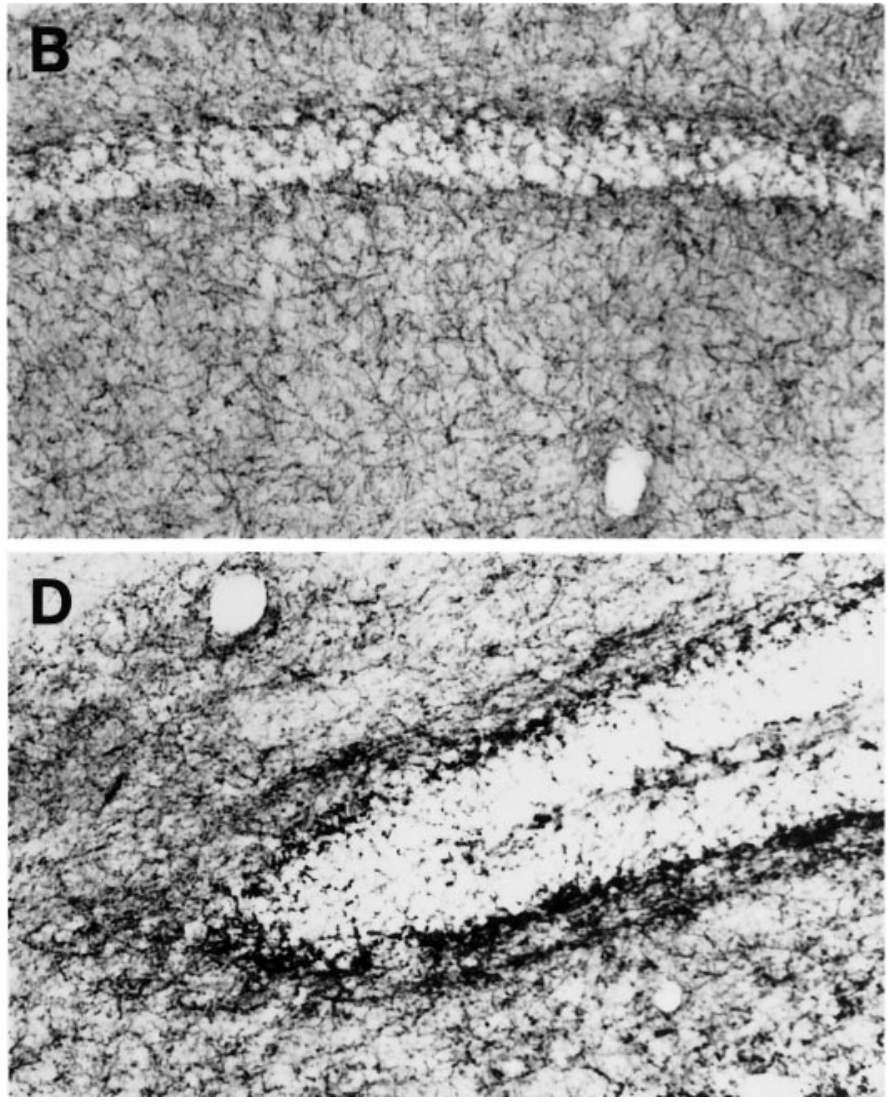

Figure 5. Aberrant cholinergic innervation of the hippocampus in $\mathrm{p} 75^{\mathrm{NTR}}$ null mutant mice. $A, B$, ChAT-immunoreactive cholinergic fibers in CA1 of the hippocampus appear more numerous in p $75^{\mathrm{NTR}}-1-$ mice. Cholinergic innervation is increased in the oriens layer (or) and stratum radiatum $(\mathrm{ra})$, which are moderately innervated in the $\mathrm{p} 75^{\mathrm{NTR}}+/+$ mice, and decreased in the suprapyramidal layer $(s p)$, which is heavily innervated in p $75^{\mathrm{NTR}}+/+$ mice. $C, D$, Profound increase in ChAT-immunoreactive cholinergic fibers in the dentate gyrus is observed in the p $75^{\text {NTR }}-/-$ mice. Cholinergic innervation is increased in both the supragranular $(s g)$ and molecular layers $(m l) . p$, Pyramidal layer; $g$, granule cell layer; $h$, hilus of the dentate gyrus. Scale bar, $100 \mu \mathrm{M}$.

molecular layer (Fig. 5D). Similar changes in the distribution of cholinergic innervation also were observed using AChE histochemistry (data not shown), indicating that these changes reflected altered target innervation rather than region-specific alterations in ChAT levels. These changes were present throughout the entire hippocampal formation.

Quantitative analysis (Fig. 6) of ChAT-immunoreactive fibers in the CA1 region of the hippocampus revealed a significant $18 \%$ increase ( $p<0.01$, Student's $t$ test) in the overall number of ChAT-positive fibers in $\mathrm{p} 75^{\mathrm{NTR}}-/-$ mice. The number of ChAT-immunoreactive fibers also was increased $9 \%$ in $\mathrm{p} 75^{\text {NTR }}$ $+/-$ mice, although this difference did not reach statistical significance. Nevertheless, statistical analysis revealed that this increase in the number of ChAT-immunoreactive fibers exhibited a significant gene dosage effect $(p<0.01$, Kruskal-Wallis nonparametric ANOVA test). The effect of genotype on fiber number in each of the three layers constituting the CA region (oriens, stratum radiata, and suprapyramidal) also was assessed individually. The absence of $\mathrm{p} 75^{\mathrm{NTR}}$ resulted in a significant $44 \%$ increase in the number of fibers in the oriens layer $(p<0.005)$, a $25 \%$ increase in the stratum radiata $(p<0.05)$, and a significant $43 \%$ decrease in the suprapyramidal layer $(p<0.005)$. In p $75^{\text {NTR }}+/-$ mice the number of ChAT-immunoreactive fibers was increased by $15 \%$ in the oriens layer and $10 \%$ in stratum radiata, although these differences did not reach statistical significance.

\section{Absence of $\mathbf{p 7 5}{ }^{\mathrm{NTR}}$ causes increased ChAT activity in medial septum and hippocampus}

ChAT is the synthetic enzyme for acetylcholine, and its activity is a well characterized marker for the neurotrophic status of cholinergic neurons (Mobley et al., 1985, 1986). As shown in Figure 7 , the complete absence of p $75^{\text {NTR }}$ caused a $30 \%$ increase in ChAT activity in the medial septum ( $p<0.005$; Student's $t$ test, $n=5$ mice for each genotype) and a $52 \%$ increase in the hippocampus $(p<0.0001, n=4$ mice for $\mathrm{p} 75+/+, n=5$ mice for $\mathrm{p} 75-/-$ mice). In p $75^{\mathrm{NTR}}+/-$ mice a $12 \%$ increase in ChAT activity was observed in the medial septum, and a $14 \%$ increase was observed in the hippocampus; these increases did not reach statistical significance.

\section{Absence of $\mathrm{p} 75^{\mathrm{NTR}}$ has no effect on adult striatal cholinergic neurons}

In contrast to the basal forebrain, there is little (if any) expression of p75 NTR in adult striatal cholinergic neurons (Koh and Loy, 1989; Mobley et al., 1989; Pioro and Cuello, 1990; Butcher, 1995). 


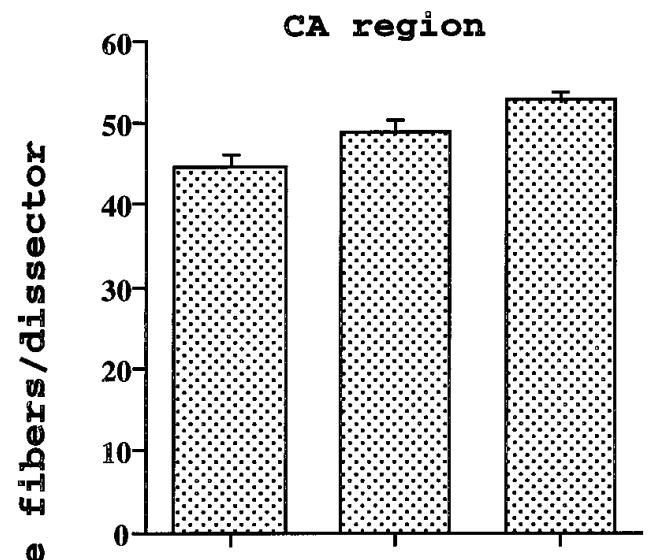

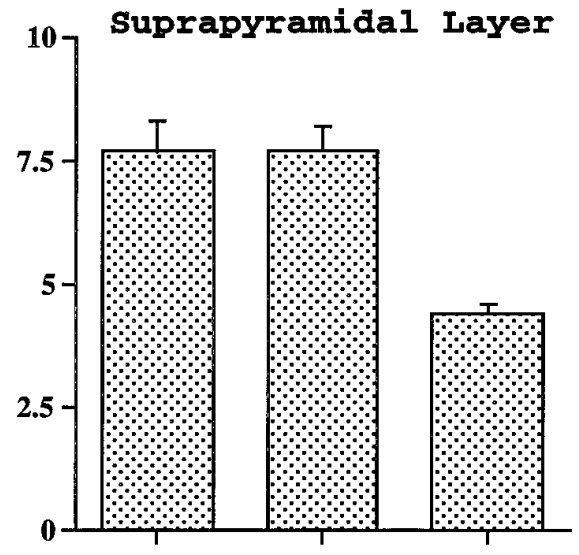

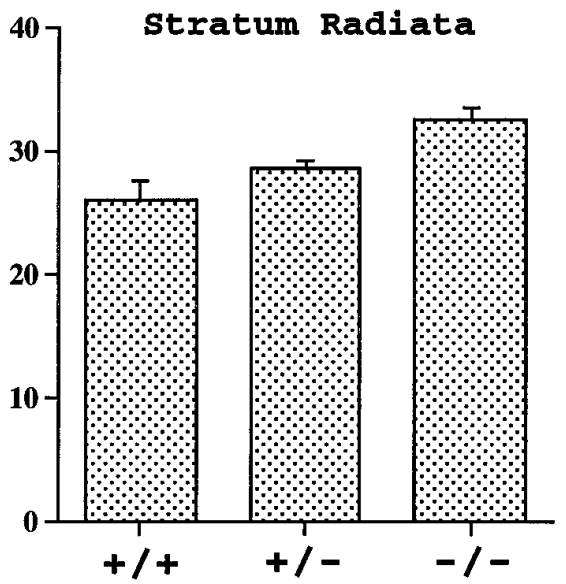

Figure 6. Quantitative analysis of cholinergic fibers in the hippocampus. The number of ChAT-immunoreactive fibers in hippocampal CA1 and in each of the three layers constituting the CA region was analyzed. There is an overall increase in ChAT-immunoreactive fibers in the CA1 region in $\mathrm{p} 75^{\mathrm{NTR}}-/-$ mice, with a differential variation in each layer. For each animal, five sections were counted for each region; the number of animals analyzed for each genotype is as follows: $+/+, 4 ;+/-, 3 ;-/-, 4$. The data are the number of ChATimmunoreactive fibers per optical disector, presented as mean \pm SEM. For CA1 region: $+/+=44.5 \pm 1.7 ;+/-=48.7 \pm$ $1.6 ;-/-=52.6 \pm 1.2$. For the oriens layer: $+/+=10.9 \pm 0.8 ;+/-=12.5 \pm$ $0.6 ;-/-=15.7 \pm 0.4$. For suprapyramidal layer: $+/+=7.7 \pm 0.6 ;+/-=7.7 \pm$ $0.5 ;-/-=4.4 \pm 0.2$. For stratum radiata: $+/+=25.9 \pm 1.6 ;+/-=28.5 \pm$ $0.7 ;-/-=32.5 \pm 0.9$.
To determine whether the observed changes in $\mathrm{p} 75^{\mathrm{NTR}}$ null mutant mice were specific for neurons expressing $p 75^{\mathrm{NTR}}$, we measured striatal cholinergic neuron number, size, and ChAT activity in the adult. Initial histological analysis revealed no difference in cholinergic neuron number or size between p75 +/ + and p75 - / mice. Quantitative analysis with unbiased stereological methods showed no difference in cholinergic neuron number $(\mathrm{p} 75+/+, 3975 \pm 88$ vs p75 -/-, $4019 \pm 282 ; n=3$ mice for each genotype, mean \pm SEM) or size $(\mathrm{p} 75+/+, 147.9 \pm 6.8$ vs p75 -/-, $146.0 \pm 7.1 ; n=3$ mice for each genotype; 100 neurons measured per mouse) between the two genotypes. No difference in number or size of cholinergic neurons in p75 $+/-$ mice was observed (data not shown). Similarly, there was no significant difference in ChAT activity in the striatum across all three genotypes (Fig. 7).

\section{NGF levels are not altered in $\mathbf{p 7 5} 5^{\mathrm{NTR}}-/-$ mice}

Because both endogenous and exogenous NGF have been shown to upregulate basal forebrain cholinergic neuron size and ChAT activity (Gnahn et al., 1983; Mobley et al., 1986; Li et al., 1995) and to promote cholinergic neurite outgrowth (Hagg and Varon, 1993), NGF levels in basal forebrain and target regions were measured (Fig. 8). The absence of p75 NTR did not cause a significant change in NGF level in either the medial septum or its target areas, including hippocampus, retrosplenial cortex, and cingulate cortex. This lack of change in NGF levels indicated that the cholinergic hypertrophy, increased medial septum and hippocampal ChAT activity, and increased target innervation were not a result of increased NGF.

\section{DISCUSSION}

The finding that the absence of $\mathrm{p} 75^{\mathrm{NTR}}$ causes an increase in neuronal size and ChAT activity supports the hypothesis that $\mathrm{p} 75^{\mathrm{NTR}}$ negatively regulates the trophic status of basal forebrain cholinergic neurons. In contrast, previous studies in $\mathrm{p} 75^{\mathrm{NTR}}$ null mutant mice demonstrated a facilitatory role for $\mathrm{p} 75^{\mathrm{NTR}}$ in both the sensory and sympathetic neuronal systems (Lee et al., 1992, 1994a; Davies et al., 1993). Although the absence of p75 NTR resulted in decreased target innervation in the sympathetic system (Lee et al., 1994b), we observed an overall increase in hippocampal cholinergic innervation. Taken together, these data indicate that $\mathrm{p} 75^{\mathrm{NTR}}$ can either positively or negatively influence neurotrophic features and that the context in which $p 75^{\text {NTR }}$ is expressed has an important influence on its actions (Rabizadeh and Bredesen, 1994; Chao and Hempstead, 1995; Greene and Kaplan, 1995; Carter and Lewin, 1997; Davies, 1997).

NGF seems to be the most potent among all neurotrophins in its effects on the number and size of basal forebrain cholinergic neurons (Koliatsos, 1994). Numerous studies have demonstrated that an increase in NGF levels leads to an upregulation of neurotrophic features in basal forebrain cholinergic neurons in vivo (Mobley et al., 1986; Fischer et al., 1987; Hartikka and Hefti, 1988). A critical paradox observed in this study was that the absence of $\mathrm{p} 75^{\mathrm{NTR}}$ resulted in an apparent increase in neurotrophic status of basal forebrain cholinergic neurons, and these features were not associated with increased NGF levels. It is noteworthy that the magnitude of neuronal hypertrophy observed in $\mathrm{p} 75^{\mathrm{NTR}}$ null mutant mice was similar to that observed after 


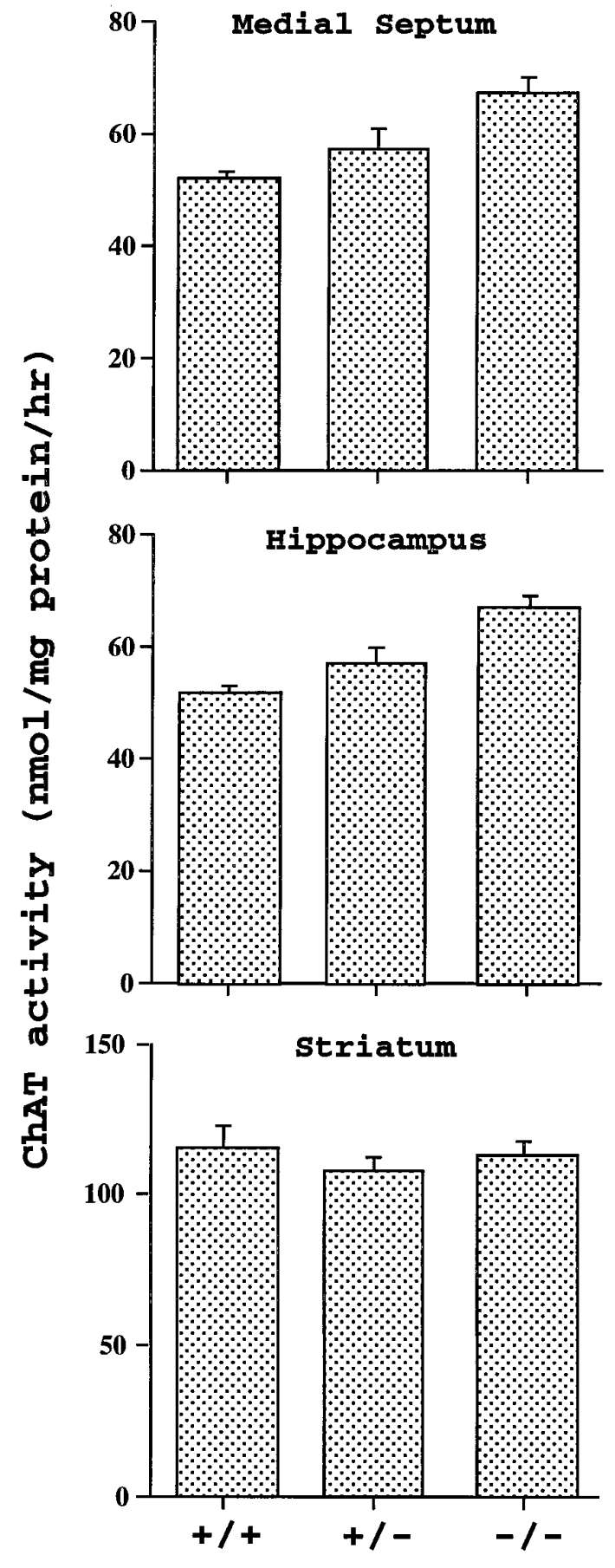

Figure 7. ChAT activity in medial septum, hippocampus, and striatum. The amount of acetylcholine synthesized is used as an indication of ChAT enzyme activity. In p75 NTR $-/-$ mice ChAT activity is increased in both the medial septum and hippocampus, but not in the striatum. Triplicate samples were measured for each region from each animal, and duplicate samples were measured for background ChAT activity for each region from each animal. Because the background for each sample was lower than $1 \%$ of total value, the data were not corrected for background. The number of animals used for each region of each genotype is as follows. Medial septum: $+/+=5 ;+/-=4 ;-/-=5$. Hippocampus: $+/+=4 ;+/-=4 ;-/-=5$. Striatum: $+/+=5 ;+/-=$ $4 ;-/-=6$. The data are nanomoles of acetylcholine per milligram of protein per hour, presented as mean \pm SEM. For medial septum: $+1+=$ $51.6 \pm 1.2 ;+/-=57.0 \pm 3.8 ;-/-=67.1 \pm 2.9$. For hippocampus: $+/+$ $=45.9 \pm 1.4 ;+/-=52.2 \pm 3.0 ;-/-=69.7 \pm 1.8$. For striatum: $+/+=$ $114.9 \pm 7.6 ;+/-=107.8 \pm 4.5 ;-/-=112.8 \pm 4.8$.
NGF infusion (Higgins et al., 1989; Chen and Gage, 1995; Martinez-Serrano et al., 1995). These findings raise two possibilities. The absence of $\mathrm{p} 75^{\mathrm{NTR}}$ in basal forebrain cholinergic neurons may result in an increased responsiveness to NGF and/or other neurotrophins or to the signaling pathways activated by TrkA or other Trk receptors. Alternatively, p $75^{\text {NTR }}$ may function independently to suppress biochemical or morphological features of basal forebrain cholinergic neurons.

The first possibility suggests that signal transduction via Trk receptors might be more effective in the absence of a potential "suppressor" function of p75 NTR (Clary and Reichardt, 1994; Greene and Kaplan, 1995; Taglialatela et al., 1996; Bredesen and Rabizadeh, 1997). Interestingly, previous quantitative doseresponse studies using sympathetic and dorsal root ganglion sensory neurons derived from $\mathrm{p} 75^{\mathrm{NTR}}$ null mutant mice demonstrated that NGF had reduced, rather than increased, potency through TrkA in the absence of p75 NTR (Davies et al., 1993; Lee et al., 1994a; Longo et al., 1997). These observations suggest complex, multifaceted $\mathrm{p} 75^{\mathrm{NTR}}$ functions that may positively or negatively mediate neurotrophic parameters. It is likely that such functions are influenced by (1) the cell type in which it is expressed, (2) whether or not Trk receptors are coexpressed, (3) the regional and developmental context in which the effects of p75 ${ }^{\text {NTR }}$ are being examined, and (4) whether or not NGF and/or other neurotrophins are present. Studies with basal forebrain cholinergic neuronal cultures will be required to show whether the response to NGF and/or other neurotrophins is altered in the absence of $\mathrm{p} 75^{\mathrm{NTR}}$.

The second possibility, that $\mathrm{p} 75^{\mathrm{NTR}}$ may act independently to negatively regulate neurotrophic status, is supported by recent findings that $\mathrm{p} 75^{\mathrm{NTR}}$ can trigger signal transduction directly in the absence of TrkA (Dobrowsky et al., 1994; Carter et al., 1996). Several studies have shown that $\mathrm{p} 75^{\mathrm{NTR}}$ functions to mediate cell death in the absence of NGF (Rabizadeh et al., 1993; Barrett and Bartlett, 1994; Barrett and Georgiou, 1996). Others have demonstrated that NGF binding to $\mathrm{p} 75^{\mathrm{NTR}}$ in the absence of TrkA mediates cell death (Casaccia-Bonnefil et al., 1996; Frade et al., 1996). This is consistent with the view of Van der Zee et al. (1996) that the increase in the number of basal forebrain cholinergic neurons in $\mathrm{p} 75^{\mathrm{NTR}}$ null mutant mice occurred mainly among TrkA-negative neurons. Whether $\mathrm{p} 75^{\mathrm{NTR}}$ negatively regulates cholinergic neuronal phenotype via TrkA-dependent or TrkA-independent mechanisms remains to be established. Nevertheless, the novel observation of the present study that the size of TrkA-positive neurons was increased in $\mathrm{p} 75^{\mathrm{NTR}}$ null mutant mice demonstrates that $\mathrm{p} 75^{\mathrm{NTR}}$ can have a negative regulatory effect in the presence of TrkA.

The observation that the effect of the suppression of cholinergic neurotrophic features by $\mathrm{p} 75^{\mathrm{NTR}}$ is gene dosage-dependent provides additional insight into potential p75 mechanisms. A novel finding in this study regarding the effect of p75 on the number of ChAT-positive neurons is that this increase occurred only when both p75 NTR alleles were absent. That only one functional p75 ${ }^{\text {NTR }}$ allele was required for its full effect on reducing the number of ChAT-positive neurons suggests that $\mathrm{p} 75^{\mathrm{NTR}}$ dominantly regulates the function of other proteins important for this phenotype. In contrast, the presence of one functional allele was associated with only a partial effect on reducing neuron size. The differential effect of $\mathrm{p} 75^{\mathrm{NTR}}$ gene dosage on neuronal number and size further supports the view that $\mathrm{p} 75^{\mathrm{NTR}}$ functions can be mediated via different mechanisms. Alternatively, these different 


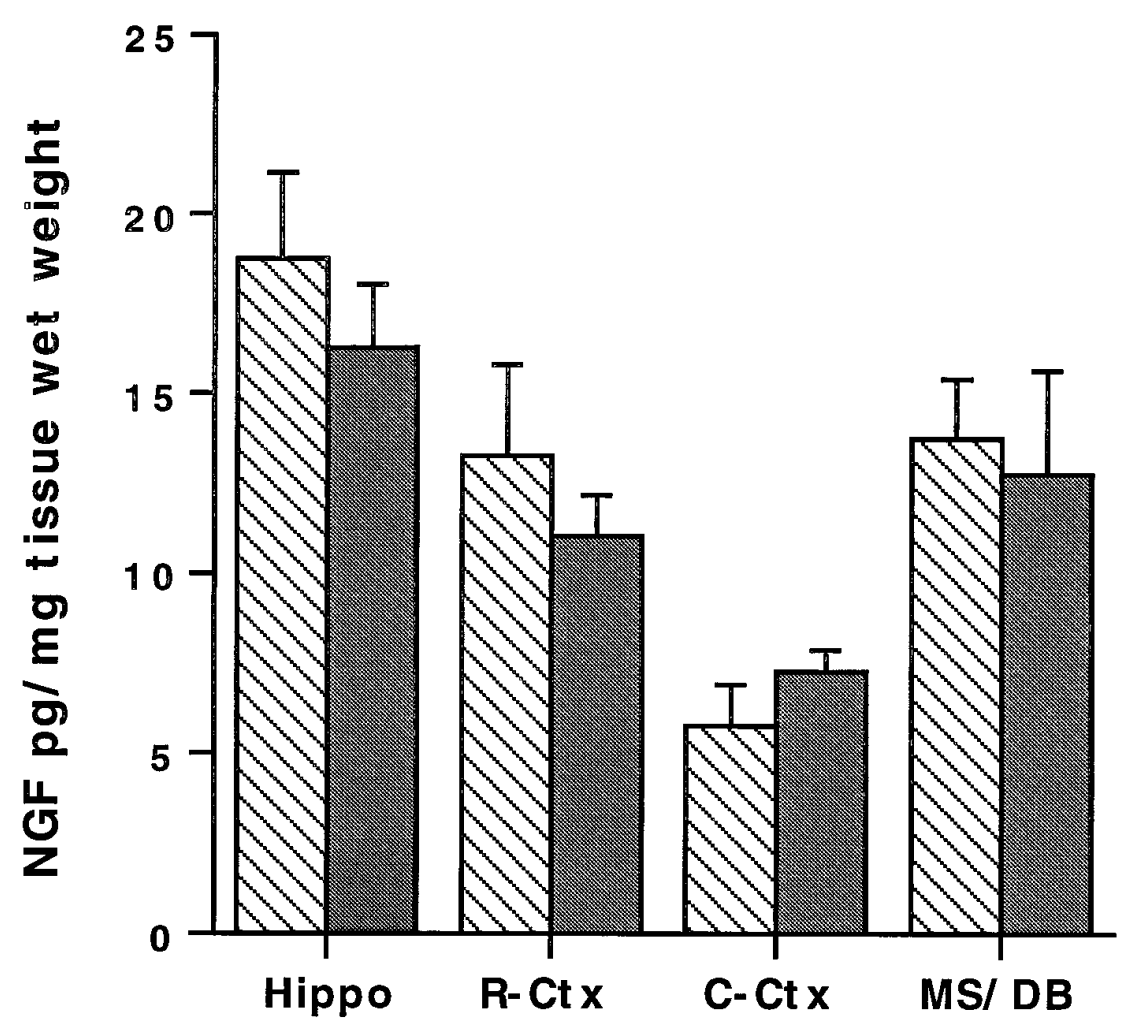

Figure 8. NGF levels in cholinergic nuclei and target areas. NGF protein levels in medial septum (consists of most of the medial septum and part of the diagonal band; $M S / D B$ ) and its associated target areas (hippocampus, Hippo; retrosplenial cortex, $R$-Ctx; cingulate cortex, $C$ $C t x)$ and in $\mathrm{p} 75^{\mathrm{NTR}}+/+$ (striped bars) and $\mathrm{p} 75^{\mathrm{NTR}}-/-$ (shaded bars) mice were determined by two-site NGF ELISA. There is no difference in NGF levels between $\mathrm{p} 75^{\mathrm{NTR}}+/+$ and $\mathrm{p} 75^{\mathrm{NTR}}-/-$ mice. Values are absorbance-normalized to a standard curve and are expressed as picograms of NGF per milligram of wet tissue weight, presented as mean \pm SEM, and are not corrected for recovery (average recovery, 89\%). Twelve mice from each genotype were used for assays of hippocampus; hippocampi from two animals were pooled as one sample ( $n=6$ samples/genotype), and samples were assayed at least twice: $+/+=18.7 \pm 2.8 ;-/-=16.2 \pm 2.1$. Six mice from each genotype were used for assays of cingulate cortex and retrosplenial cortex; cortices from two mice were pooled as one sample ( $n=3$ samples/genotype) and assayed at least twice. For retrosplenial cortex: $+/+=13.2 \pm 2.9 ;-/-=11.0 \pm 1.4$. For cingulate cortex: $+/+=5.7 \pm 1.5 ;-/-=7.2 \pm 0.3$. Twelve mice from each genotype were used for assays of medial septum; $M S / D B$ regions from six mice were pooled as one sample $(n=2$ samples/genotype $):+/+=13.8 \pm 2.0$; $-/-=12.7 \pm 3.2$. effects of $\mathrm{p} 75^{\mathrm{NTR}}$ might be a function of different thresholds for p $75^{\text {NTR }}$ modulation of neuronal survival and cell size.

The increases in ChAT activity in the medial septum of p $75^{\text {NTR }}$ null mutant mice raised the possibility that upregulation of ChAT activity may have facilitated the identification of cholinergic neurons. Consistently, in the null mutant mice ChAT immunoreactivity was increased in the cell bodies of the basal forebrain cholinergic neurons. Previous studies have demonstrated that upregulation of cholinergic markers by NGF infusion and downregulation of ChAT after fimbria-fornix transection can alter the number of cholinergic neurons detected in the medial septum (Hagg et al., 1988, 1989; Higgins et al., 1989). Thus, in addition to decreased cell death, increased detection of cholinergic neurons also may have contributed, in part, to the observed increase in the number of septal cholinergic neurons in p $75^{\text {NTR }}$ null mutant mice. Similarly, upregulation of ChAT also may have contributed to the observed increase in the number of ChATpositive fibers in the hippocampus. However, it is apparent that the absence of $\mathrm{p} 75^{\mathrm{NTR}}$ did result in an alteration of target innervation, because ChAT-positive fibers were decreased in the layer that normally is heavily innervated and were increased elsewhere. The change in target innervation pattern could have been caused by a failure to eliminate excess fibers during development or by increased cholinergic sprouting. The septalhippocampal cholinergic network seems to be involved in learning and memory (Woolf et al., 1984; Butcher, 1995; Dutar et al., 1995). Thus, the finding that $\mathrm{p} 75^{\mathrm{NTR}}$ negatively regulates cholinergic hippocampal innervation raises the possibility that excessive or unopposed p75 NTR function might impair memory and/or other cognitive function.

The observed increase in the number of basal forebrain cholinergic neurons in p75 -/- mice in the present study is consistent with the previous report by Van der Zee and colleagues (1996). Contrary to this previous report, using strain-matched littermate controls, we found no difference in the number of striatal cholinergic neurons between $\mathrm{p} 75+/+$ and $-/-$ mice. The present study also found no difference in the size of striatal cholinergic neurons nor striatal ChAT activity between p75 +/ + and $-/-$ mice. This discrepancy could be attributable to the difference in control strains used between the two studies. In the previous report (Van der Zee et al., 1996) three individual homogeneous strains (129/Sv, BALB/c, and C57Bl/6J/black 29) were used as wild-type controls in contrast to the $\mathrm{p} 75-/-$ mice consisting a mixed strain background (C57B6/BALB/c/129). The present finding that the absence of $\mathrm{p} 75^{\mathrm{NTR}}$ caused a significant increase in the number, size, and ChAT activity in cholinergic neurons in the basal forebrain and not in the striatum (which express little, if any, p $75^{\mathrm{NTR}}$ in the adult animals) suggests that the negative regulatory effect of $\mathrm{p} 75^{\mathrm{NTR}}$ in adult animals is specific for cholinergic neurons expressing $\mathrm{p} 75^{\mathrm{NTR}}$.

The phenotypes revealed in this study also can be viewed in the context of those identified in NGF and TrkA mutant mice. As in p75 ${ }^{\text {NTR }}$ mutant mice, the absence of NGF and TrkA had no detectable effect on the gross structure of the basal forebrain cholinergic system (Crowley et al., 1994; Smeyne et al., 1994; Snider, 1994). On the cellular level, both NGF- and TrkAdeficient mice demonstrated decreased cholinergic phenotypes in the basal forebrain. The distinct phenotypes between NGF/ TrkA-deficient mice and $\mathrm{p} 75^{\mathrm{NTR}}$ mutant mice suggest that the actions of $\mathrm{p} 75^{\mathrm{NTR}}$ cannot be viewed as simply facilitating the neurotrophic effects of NGF. These differences in phenotypes further support the view that $\mathrm{p} 75^{\mathrm{NTR}}$ can act to negatively modulate neuronal functions.

\section{REFERENCES}

Auburger G, Heumann R, Hellweg R, Korsching S, Thoenen H (1987) Developmental changes of the nerve growth factor and its mRNA in the rat hippocampus: comparison with choline acetyltransferase. Dev Biol 120:322-328. 
Barrett GL, Bartlett PF (1994) The p75 nerve growth factor receptor mediates survival or death depending on the stage of sensory neuron development. Proc Natl Acad Sci USA 91:6501-6505.

Barrett GL, Georgiou A (1996) The low-affinity nerve growth factor receptor $\mathrm{p} 75^{\mathrm{NGFR}}$ mediates death of $\mathrm{PC} 12$ cells after nerve growth factor withdrawal. J Neurosci Res 45:117-128.

Bredesen DE, Rabizadeh S (1997) p75 NTR and apoptosis: Trk-dependent and Trk-independent effects. Trends Neurosci 20:287-290.

Bull G, Oderfeld-Nowak B (1971) Standardization of a radiochemical assay of cholinergic acetyltransferase. J Neurochem 18:935-947.

Butcher LL (1983) Acetylcholinesterase histochemistry. In: Handbook of chemical neuroanatomy, Vol 1, Methods in chemical neuroanatomy (Bjorklund A, Hokfelt T, eds), pp 1-49. Amsterdam: Elsevier.

Butcher LL (1995) Cholinergic neurons and networks. In: The rat nervous system (Paxinos G, ed), pp 1003-1015. San Diego: Academic.

Carter BD, Lewin GR (1997) Neurotrophins live or let die: does p75 ${ }^{\text {NTR }}$ decide? Neuron 18:187-190.

Carter BD, Kaltschmidt C, Kaltschmidt B, Offenhauser N, BohmMatthaei R, Baeuerle PA, Barde Y-A (1996) Selective activation of NF-kB by nerve growth factor through the neurotrophin receptor $\mathrm{p} 75$. Science 272:542-545.

Casaccia-Bonnefil P, Carter BD, Dobrowsky RT, Chao MV (1996) Death of oligodendrocytes mediated by the interaction of nerve growth factor with its receptor p75. Nature 383:716-719.

Chao MV, Hempstead BL (1995) p75 and Trk: a two-receptor system. Trends Neurosci 18:321-326.

Chen KS, Gage FH (1995) Somatic gene transfer of NGF to the aged brain: behavioral and morphological amelioration. J Neurosci 15:2819-2825.

Clary DO, Reichardt LF (1994) An alternative spliced form of the nerve growth factor receptor TrkA confers an enhanced response to neurotrophin 3. Proc Natl Acad Sci USA 91:11133-11137.

Clary DO, Weskamp G, Austin LR, Reichardt LF (1994) TrkA crosslinking mimics neuronal responses to nerve growth factor. Mol Biol Cell 5:549-563.

Crowley C, Spencer SD, Nishimura MC, Chen KS, Pitts-Meek S, Prmanini MP, Ling LH, McMahon SB, Shelton DL, Levinson AD, Phillips HS (1994) Mice lacking nerve growth factor display prenatal loss of sensory and sympathetic neurons yet develop basal forebrain cholinergic neurons. Cell 76:1001-1011.

Davies AM (1997) Neurotrophins: the yin and yang of nerve growth factor. Curr Biol 7:R38-R40.

Davies AM, Lee K-F, Jaenisch R (1993) p75-deficient trigeminal sensory neurons have an altered response to NGF but not to other neurotrophins. Neuron 11:565-574.

Dobrowsky RT, Werner MH, Castellino AM, Chao MV, Hannun YA (1994) Activation of the sphingomyelin cycle through the low-affinity neurotrophin receptor. Science 265:1596-1599.

Dutar P, Bassant MH, Senut MC, Lamour Y (1995) The septalhippocampal pathway: structure and function of a central cholinergic system. Physiol Rev 75:393-427.

Fischer W, Wictorin K, Bjorklund A, Williams LR, Varon S, Gage FH (1987) Amelioration of cholinergic neuron atrophy and spatial memory impairment in aged rats by nerve growth factor. Nature 329:65-68.

Frade JM, Rodriguez-Tebar A, Barde Y-A (1996) Induction of cell death by endogenous nerve growth factor through its p75 receptor. Nature 383:166-168.

Gould E, Woolf NJ, Butcher LL (1991) Postnatal development of cholinergic neurons in the rat. I. Forebrain. Brain Res Bull 27:767-789.

Grahn H, Hefti F, Heumann R, Schwab ME, Thoenen H (1983) NGFmediated increase of choline acetyltransferase (ChAT) in the neonatal rat forebrain: evidence for a physiological role of NGF in the brain. Dev Brain Res 9:45-52.

Greene LA, Kaplan DR (1995) Early events in neurotrophin signaling via Trk and p75 receptor. Curr Opin Neurobiol 5:579-587.

Hagg T, Varon S (1993) Neurotropism of nerve growth factor for adult rat septal cholinergic axons in vivo. Exp Neurol 119:37-45.

Hagg T, Manthorpe M, Vahlsing HL, Varon S (1988) Delayed treatment with nerve growth factor reverses the apparent loss of cholinergic neurons after acute brain damage. Exp Neurol 101:303-312.

Hagg T, Fass-Holmes B, Vahlsing HL, Manthorpe M, Conner JM, Varon S (1989) Nerve growth factor reverses axotomy-induced decrease in choline acetyltransferase, NGF receptor, and size of medial septum cholinergic neurons. Brain Res 505:29-38.

Hartikka J, Hefti F (1988) Development of septal cholinergic neurons in culture: plating density and glial cells modulate effects of NGF on survival, fiber outgrowth, and expression of transmitter-specific enzymes. J Neurosci 8:2967-2985.

Hefti F, Araujo D, Beck KD, Knusel B, Lapchak PA, Michel PP, Ohsawa F (1993) Experimental systems to study neurotrophic factor effects on rat brain cells. In: Neuromethods, Vol 25, Neurotrophic factors (Boulton A, Baker G, Hefti F, eds), pp 291-329. Totowa, NJ: Humana.

Hendersen Z (1996) Responses of basal forebrain cholinergic neurons to damages in the adult brain. Prog Neurobiol 48:219-254.

Higgins GA, Koh S, Chen KS, Gage FH (1989) NGF induction of NGF receptor gene expression and cholinergic neuronal hypertrophy within the basal forebrain of adult rat. Neuron 3:247-256.

Johnston MV, Rutkowski JL, Wainer BH, Long JB, Mobley WC (1987) NGF effects on developing forebrain cholinergic neurons are regionally specific. Neurochem Res 12:985-994.

Koh S, Loy R (1989) Localization and development of nerve growth factor-sensitive rat basal forebrain neurons and their afferent projection to hippocampus and neocortex. J Neurosci 9:2999-3018.

Kojima M, Takahashi N, Ikeuchi T, Hatanaka H (1992) Nerve growth factor (NGF)-mediated up-regulation of low-affinity NGF receptor gene expression in cultured basal forebrain cholinergic neurons from postnatal 3-day-old rats. Mol Brain Res 16:267-273.

Koliatsos VE, Price KL, Gouras GK, Cayouette MH, Burton LE, Winslow JW (1994) Highly selective effects of NGF, BDNF, and NT-3 on intact and injured basal forebrain magnocellular neurons. J Comp Neurol 343:247-262.

Korsching S, Auburger G, Heumann R, Scott J, Thoenen H (1985) Levels of nerve growth factor and its mRNA in the central nervous system of the rat correlate with cholinergic innervation. EMBO J 4:1389-1393.

Large TH, Bodary SC, Clegg DO, Weskamp G, Otten U, Reichardt LF (1986) Nerve growth factor gene expression in the developing rat brain. Science 234:352-355.

Lee KF, Li E, Huber LJ, Landis SC, Sharpe AH, Chao MV, Jaenisch R (1992) Targeted mutation of the gene encoding the low affinity NGF receptor $\mathrm{p} 75$ leads to deficits in the peripheral sensory nervous system. Cell 69:737-749.

Lee KF, Davies AM, Jaenisch R (1994a) p75-deficient embryonic dorsal root sensory and neonatal sympathetic neurons display a decreased sensitivity to NGF. Development 120:1027-1033.

Lee KF, Bachman K, Landis S, Jaenisch R (1994b) Dependence on p75 for innervation of some sympathetic targets. Science 263:1447-1449.

Li Y, Holtzman DM, Kromer LF, Kaplan DR, Chua-Couzens J, Clary DO, Knusel B, Mobley WC (1995) Regulation of TrkA and ChAT expression in developing rat basal forebrain: evidence that both exogenous and endogenous NGF regulate differentiation of cholinergic neurons. J Neurosci 15:2888-2905.

Longo FM, Manthorpe M, Xie YM, Varon S (1997) Synthetic NGF peptide derivatives prevent neuronal death via a p75 receptordependent mechanism. J Neurosci Res 48:1-17.

Lucidi-Phillipi CA, Clary DO, Reichardt LF, Gage FH (1996) TrkA activation is sufficient to rescue axotomized cholinergic neurons. Neuron 16:653-663.

Martinez-Serrano A, Fischer W, Bjorklund A (1995) Reversal of agedependent cognitive impairments and cholinergic neuronal atrophy by NGF-secreting neuronal progenitors grafted to the basal forebrain. Neuron 15:473-484.

Mobley WC, Rutkowski JL, Tennekoon GI, Buchanan K, Johnston MV (1985) Choline acetyltransferase activity in striatum of neonatal rats increased by nerve growth factor. Science 229:284-287.

Mobley WC, Rutkowski JL, Tennekoon GI, Gemski J, Buchanan K, Johnston MV (1986) Nerve growth factor increases choline acetyltransferase activity in developing basal forebrain neurons. Mol Brain Res 1:53-62.

Mobley WC, Woo JE, Edwards RH, Riopelle RJ, Longo FM, Weskamp G, Otten U, Valletta JS, Johnston MV (1989) Developmental regulation of nerve growth factor and its receptor in the rat caudate-putamen. Neuron 3:655-664.

Pioro EP, Cuello AC (1990) Distribution of nerve growth factor receptor-like immunoreactivity in the adult rat central nervous system. Effect of colchicine and correlation with the cholinergic system. I. Forebrain. Neuroscience 34:57-87.

Rabizadeh S, Bredesen DE (1994) Is p75 NGFR involved in developmental neural cell death? Dev Neurosci 16:207-211.

Rabizadeh S, Oh J, Zhong L, Yang J, Bitler CM, Butcher LL, Bredesen 
DE (1993) Induction of apoptosis by the low-affinity NGF receptor. Science 261:345-348.

Rabizadeh S, Bitler CM, Butcher LL, Bredesen DE (1994) Expression of the low-affinity nerve growth factor enhances beta-amyloid peptide toxicity. Proc Natl Acad Sci USA 91:10703-10706.

Smeyne RJ, Klein R, Schnapp A, Long LK, Bryant S, Lewin A, Lira SA, Barbacid M (1994) Severe sensory and sympathetic neuropathies in mice carrying a disrupted Trk/NGF receptor gene. Nature 368:246-249.

Snider WD (1994) Functions of the neurotrophins during nervous system development: what the knockouts are teaching us. Cell 77:627-638.

Taglialatela G, Hibbert CJ, Hutton LA, Werrbach-Perez K, Perez-Polo JR (1996) Suppression of $p 140^{\text {trkA }}$ does not abolish nerve growth factor-mediated rescue of serum-free PC12 cells. J Neurochem 66:1826-1835.

Tomlinson BE (1992) Aging and the dementias. In: Greenfield's neuropathology (Adams JH, Duchen LW, eds), pp 1284-1410. New York: Oxford UP.

Van der Zee CEEM, Ross GM, Riopelle RJ, Hagg T (1996) Survival of cholinergic forebrain neurons in developing $\mathrm{p} 75^{\mathrm{NGFR}}$-deficient mice. Science 274:1729-1732.

Woolf NJ, Eckenstein F, Butcher LL (1984) Cholinergic systems in the rat brain. I. Projections to the limbic telencephalon. Brain Res Bull 13:751-784.

Woolf NJ, Gould E, Butcher LL (1989a) Nerve growth factor receptor is associated with cholinergic neurons of the basal forebrain but not the pontomesencephalon. Neuroscience 30:143-152.

Woolf NJ, Jacobs RW, Butcher LL (1989b) The pontomesencephalotegmental cholinergic system does not degenerate in Alzheimer's disease. Neurosci Lett 96:277-282.

Yan Q, Johnson EM (1988) An immunohistochemical study of the nerve growth factor receptor in developing rats. J Neurosci 8:3481-3498.

Yeo TT, Yang T, Massa S, Zhang JS, Honkaniemi J, Butcher LL, Longo FM (1997) Deficient LAR expression causes reduced cholinergic neuronal size and loss of cholinergic hippocampal innervation. J Neurosci Res 47:348-360. 